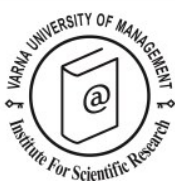

\title{
Backpackers' contribution to development and poverty alleviation: myth or reality? A critical review of the literature and directions for future research
}

\author{
Márcio Ribeiro Martins ${ }^{1 *}$ and Rui Augusto Costa ${ }^{2}$
}

Received: 18/09/2016 Accepted: 08/10/2016

\begin{abstract}
1 GOVCOPP, Department of Economics, Management, Industrial Engineering and Tourism (DEGEIT), University of Aveiro, Campus universitário de Santiago, 3810-193 Aveiro, Portugal. Phone: +351 234370361 (ext 23653); E-mail: marcioribeiromartins@ua.pt

2 GOVCOPP, Assistant Professor at Department of Economics, Management, Industrial Engineering and Tourism (DEGEIT), University of Aveiro, Campus universitário de Santiago, 3810-193 Aveiro, Portugal. Phone: +351 234370361 (ext 23653); E-mail: rui.costa@ua.pt

* Corresponding author
\end{abstract}

\begin{abstract}
Due to its great diversity and characteristics, backpackers can increase business opportunities in many destinations that decide to invest on their promotion. Those responsible for destinations planning and management will be able to conduct marketing strategies to segments that are best adapted to local or regional reality, bringing with it, important competitive advantages. It can be promoted not only in regions where the tourism sector is already well established and developed but also in more peripheral regions usually in the margins of the main tourist flows. This paper aims to present and discuss the backpacker tourism contribution to development and poverty alleviation, emphasising some theoretical aspects related to concepts, constructs and methodological options used in articles published in Scopus platform. A systematic review of literature and a qualitative and quantitative analysis were made. In a first stage data compilation and quantitative analysis of scientific articles published in Scopus database since 1960 was carried out. In a second stage, a qualitative analysis was performed. Despite few exceptions, the majority of governments worldwide continue to ignore backpacker tourism. It was confirmed the lack of quantitative studies that demonstrate, objectively, the economic impact of backpackers and it is suggested the need of quantitative data collected and analysed by statistical official agencies.
\end{abstract}

(C) 2017 Varna University of Management. All rights reserved

Keywords: Backpackers, tourism, poverty alleviation, literature review, Scopus.

Citation: Martins, M., \& Costa, R. (2017) Backpackers' contribution to development and poverty alleviation: myth or reality? A critical review of the literature and directions for future research. European Journal of Tourism Research 16, pp. 136-153

\section{Introduction}

The emergence and expansion of low-cost airlines have contributed to the growth of non- institutionalized forms of tourism that already constitute in some destinations a significant proportion of visitors, legitimizing the idea that 
one of current trends with great impact on tourist activity is the increasing number of young people who travel annually, having registered in 2012, throughout the world, more than 200 million of international travels with revenues of 183 billion US\$ (Tourism Research and Marketing, 2013). Among these, it is important to highlight the backpacker segment, a heterogeneous, complex and multifaceted phenomenon (Sørensen, 2003) that despite of being ignored or even discouraged by authorities in many countries (Hampton, 1998), some studies have recognized that its financial and social value are significant (Hampton, 1998; The Ooi \& Laing, 2010; Scheyvens, 2002). However, investigations in this area are still incipient. Associated in the past to hippies, since Cohen (1972) the academic interest for tourism backpacker has been growing. Despite the empirical and conceptual framework carried out by Loker-Murphy \& Pearce (1995) reveals the economic importance of this segment in Australia, there is still a lack of empirical and quantitative research that contributes to a better understanding of the backpackers impact and their subsegments in local economy (Richards \& Wilson, 2004). Only a small number of international studies, mostly with ethnographic and qualitative approaches, has been focusing on this issue and give more attention to its contribution to development and poverty alleviation in developing countries (Daldeniz \& Hampton, 2013; Hampton, 1998; Ooi \& Laing, 2010; Rogerson, 2007; Scheyvens, 2002). Most of the analysed studies are descriptive and deal with the flow of information that circulates between the tourists of this segment (Murphy, 2001), others, with ethnographic approaches (Sorensen, 2003) explore the demographic, social and cultural tourists characteristics. None of them make a rigorous econometric analysis of the amounts injected by backpackers into local economies as pointed out by Dayour, Adongo, \& Taale (2016).

Through a systematic literature review, this work aims to present and discuss the backpacker's contribution to development and poverty alleviation, stressing some theoretical aspects related to concepts, constructs and methodological options expressed in articles related with this market segment published in
Scopus database. The status of backpackers' contribution to development and poverty alleviation has not been evaluated systematically, which lead us to ask the questions: How much backpackers' impacts in development and poverty alleviation research has been published? What is the status of backpackers' impacts in development and poverty alleviation scholarship in terms of volume of publications, research method, and research focal areas? What is the research progress and potential for scholars?

This systematic review of literature can give an important contribution to the comprehension and interpretation of diverse and relevant research findings about backpacker's tourism economic and social value. Can also reveal the cumulative knowledge from a number of scientific papers published and scattered in several scientific journals, providing a clear direction for future research about the contribution to development and poverty alleviation of backpacker tourism.

This paper is organised as follows. After this introduction, the second section presents a conceptual review of the term backpacker, and section three presents a review of methods and conceptual framework. The fourth section presents and analyses the search results that will be discussed in the fifth section. Finally, section six covers the study's conclusions and limitations and future research directions.

\section{Backpacker conceptual review}

The backpacker tourism is a relatively recent phenomenon that has attracted the attention of several researchers either by its heterogeneity and complexity (Sørensen, 2003), by its social and economic relevance (Loker-Murphy \& Pearce, 1995; Hampton, 1998; Scheyvens, 2002; Ooi \& Laing, 2010; Rogerson, 2011), either by its cultural and ethnographic characteristics (Scheyvens, 2002; Sorensen, 2003).

One of the first authors to devote his attention to tourists behaviour and their local involvement was Cohen (1972), having proposed, in general, the existence of institutionalized and non-institutionalised forms of tourists. But since the "drifter" travellers of Cohen (1972) and the 
"wanderers" of Vogt (1976), the concept of backpacker has detached from the 'hippy' notion. The term "budget travellers" appears for the first time in the work of Riley (1988) who classifies this type of tourists as educated, belonging to the European middle class, single, traveling alone and worried about their lower budget. More recently, the term most often used to designate this tourists segment become "backpackers" (Hampton, 1998; LokerMurphy \& Pearce, 1995; A. Reichel, Fuchs, \& Uriely, 2007; Richards \& Wilson, 2004; Rogerson, 2007; Scheyvens, 2002; Tourism Research Australia, 2009), defined as tourists traveling with backpacks, with a reduced daily budget (Hampton \& Hamzah, 2010), being predominantly young, with a preference for economic accommodation and informal and flexible routes (Pearce, 1990 cited in The Ooi \& Laing, 2010).
Complex and multifaceted way of tourism (Sørensen, 2003) it is evident that there is a lack of consensus among the researchers in the current concept of backpacker (Ooi \& Laing, 2010), segment characterized by its deep awareness in controlling their costs (Scheyvens, 2002) and by a tendency to travel longer distances and seek places and experiences more unusual (Haigh, 1995, cited in Scheyvens, 2002), focusing in authenticity and the positive contact with the locals (Eadington \& Smith, 1992 cited in Maoz, 2006). Bradt (2005) cited in Hampton \& Hamzah (2010) gives emphasis to other characteristics, describing backpacker tourists as independent travelers who survive with less than US\$15 per day, using local transportations, carrying their belongings on their backs, and haggling for products and services, away from crowds and discovering new places. Pearce (1990) cited in

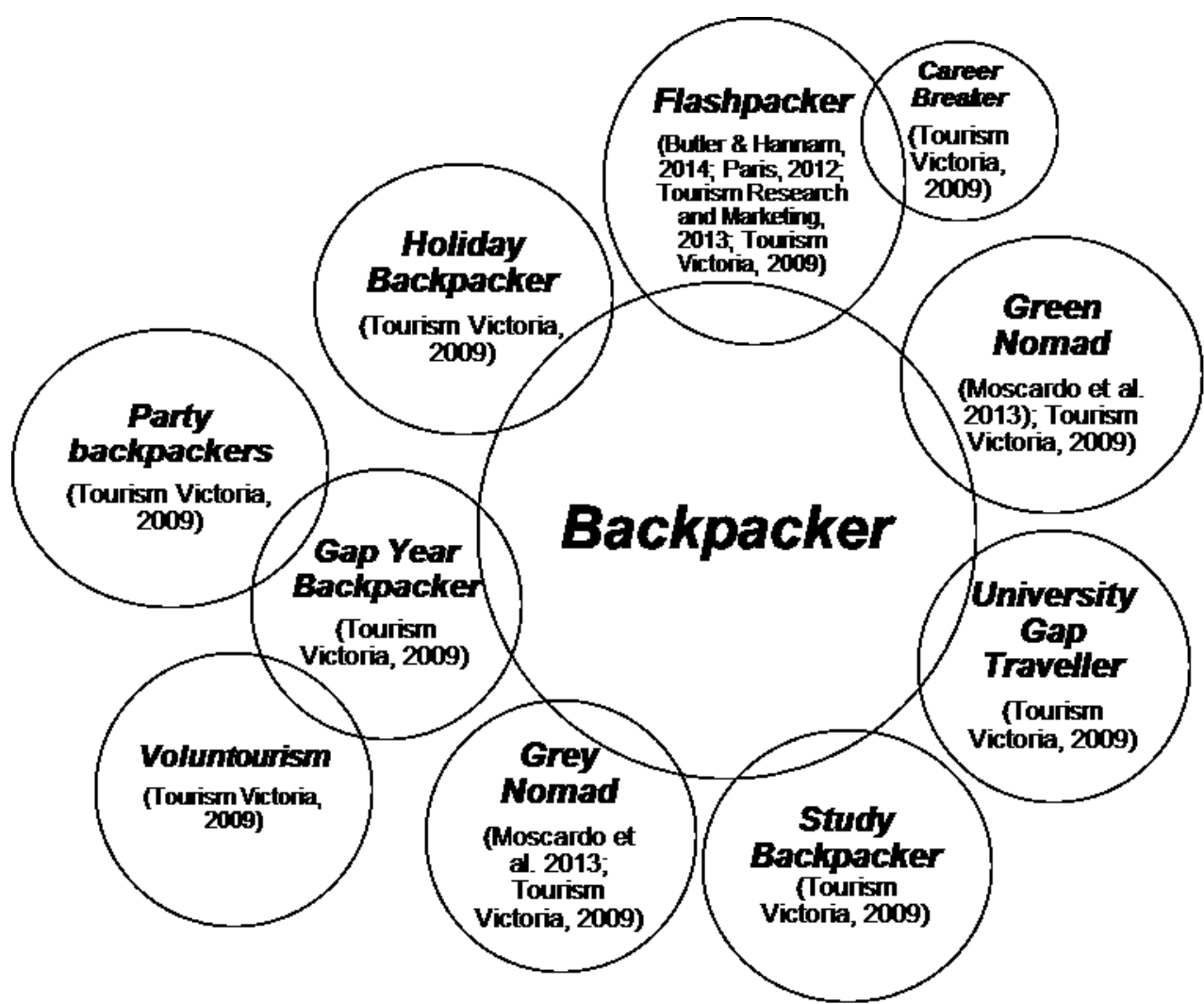

Sources: Butler \& Hannam (2014); Moscardo, Konovalov, Murphy, \& McGehee (2013); Paris (2012); Tourism Research and Marketing (2013); Tourism Victoria (2009). Author's construction

Figure 1. Subsegments of backpacker tourists. 
Ooi \& Laing (2010:194) defines backpackers "as predominantly young travellers on extended holidays with a preference for budget accommodation, a flexible and informal travel itinerary and an emphasis on meeting people and participating in a range of activities".

Due to "their tendency to collectively appropriate sites and construct identities based on a range of styles, attitudes and consumption patterns" are also known as "neo-tribes" (Gibson \& Connell, 2003:182)" or "global nomads" (Richards \& Wilson, 2004).

In China are also known as "donkey friends" coinciding to the age with the well-known "Generation Y" (Chen \& Weiler, 2014), while in Brazil are known as "duristas" and "farofeiros" (Wunder, 2000) as a consequence of their reduced travel budget.

But for Sorensen (2003), the term backpacker is more a social construct than a definition and taking into account the current diversity of this segment, in particular, the extension of time travel, the ability to represent all backpackers in accordance with Riley's (1988) proposal raises some doubts. Therefore, Sorensen (2003) proposes the term "Short-term backpacker" to designate the travellers of backpacker style but with a time budget limited to the available holidays period, in accordance to the concept of "flashpacker" analysed recently in the Paris work (2012), being used to designate the backpacker tourists that traveling with the latest technologies and for more reduced time periods also make use of a bigger budget. By looking for a better quality accommodation, get to take a break in their career or to practice a Working Holiday Making (WHM Visa) some tourists of this subsegment are designated by Carreer Breaker (Tourism Victoria, 2009).

Due to its complexity, to the various subsegments that have been identified (figure 1), and the need to include the backpacker tourists in the official statistics, the Tourism Research Australia (2009) defines the backpacker in a succinct and objective way as "a person who spends one or more nights in a backpacker's house or Hostel". Aware of the economic advantages of this segment, the Tourism Victoria (2009), Australia, recognizes the existence of several sub-segments such as: the Holiday Backpacker, composed of older tourists than the usual backpacker and that benefit from the use of short periods of vacation, sometimes repeated, having available more financial resources; Gap Year Backpacker, aged between 18-19 years who carry out a sabbatical year at the end of secondary education, which include the Party Backpackers \& Voluntourism; University Gap Traveller, characterized by being between 2024 years old, taking a break in university studies or commemorating the end of higher studies; the Study Backpacker, composed by Australian universities students, who travel during the study brakes; and the Gray Nomad that include tourists with more than 55 years, who usually like to drive their motorhome and attend boutique style hotels.

\section{Review methods and conceptual framework}

This paper aims to present and discuss the backpacker tourism contributions to local development and poverty alleviation around the world. For that purpose, articles of conceptual and empirical nature related to the economic impact of the backpacker segment were researched in Scopus database. The economic impact concepts were used because the concepts of 'development' and 'poverty alleviation' results only in 2 documents already included in previous search. The word 'sustainable' was used as well but with the same results of economic impact.

The "economic impact" as defined by Watson et al., (2007) is "the net changes in new economic activity associated with an industry, event, or policy in an existing regional economy". Studies about economic impact "model the recursive effects on income, output and employment caused by the injection of cash into an economy by a new activity" (Mayer, Müller, Woltering, Arnegger, \& Job, 2010). Tourism is an economic activity responsible for flow of currency into local, regional and national economy with direct and secondary impacts (Klijs, Heijman, Maris, \& Bryon, 2012) and as backpacker tourists, in particular, have been described as spending more money through a wider area, (Dayour et al., 2016; laquinto, 2015; Maoz, 2007; Musa \& Thirumoorthi, 2011; Peel \& Steen, 2007; 
Rogerson, 2011; Scheyvens, 2002) and because they don't purchase for luxury products and spend more on local goods and services (Gibson \& Connell, 2003; laquinto, 2015; Maoz, 2007; Moscardo et al., 2013; Scheyvens, 2002; Wunder, 2000) it is assumed by some authors that they have an important role in capital leakage reduction and in the mitigation of extreme poverty (Dayour et al., 2016; Hampton, 1998; Hamzah \& Hampton, 2013; Musa \& Thirumoorthi, 2011; Wunder, 2000) having more impact in local economies. For that reason it was expected to find articles related with backpackers economic impact and their "economic contribution" (Watson et al., 2007) to the gross change in economic activity. Nonetheless, only Dayour et al. (2016) that investigated the determinants of backpackers' aggregate expenditure and their spending on various goods within the classical utility maximisation framework explored which factors influence their spending but the lack of comparison of backpackers' expenditure with mainstream tourists didn't reveal the relative contribution of backpackers to the local economy. Consequently, backpackers' economic impact wasn't analysed yet.

There are several models that can be used to analyse the economic impacts of tourism but there are substantial differences between them in the nature and precision of results, data demands, complexity and underlying assumptions (Klijs et al., 2012). The inputoutput models and computable general equilibrium (CGE) models are currently the most common methods but the current lack of data about the sectoral supply linkages between firms that both models require, leads researchers to use the Keynesian multiplier approach (Mayer et al., 2010). Estimate of the economic impacts of tourism as done by Wagner (1997) in a Brazilian region or analysing the tourism expenditure on incomes, employment, public sector revenue and the balance of payments as Archer \& Fletcher (1996) did to the Seychelles were not done to backpacker tourism. Despite backpacker tourists have been recognized for their positive impacts on local community development, there is a lack of rigorous econometric analysis of the amounts injected into local economies as revealed by Dayour et al. (2016), and its importance for development and poverty alleviation.

The research was carried out in Scopus database because "offers a more comprehensive view of scientific production worldwide in the areas of science, technology, medicine, social sciences, Arts \& Humanities [recognized as] the largest abstract and citation database of peer-reviewed literature" (Elsevier, 2014). Data collection was carried out in January 2016 and revised in February (same year). The research was conducted in two distinct stages. In a first phase data compilation and quantitative analysis of scientific articles published since 1960 was carried out. In a second stage, the qualitative analysis has been made. The selected period of time (1960-2015) was the widest permitted by Scopus platform and all scientific areas were included. The search and code scheme used had the purpose to identify scientific articles that gather simultaneously the words "backpacker and tourism" and "economic impact", whether they were identified in the title, abstract or keywords. The obtained results are shown in table 1.

In the search it was used as well, other code schemes like "development" and "poverty alleviation" but Scopus database only returned 2 documents already included in former search. As few articles explore the economic impact of the backpacker tourism with a rigorous

Table 1. Research orientations used in articles identification.

\begin{tabular}{lllll}
\hline $\begin{array}{l}\text { Type of } \\
\text { analysis }\end{array}$ & $\begin{array}{l}\text { Period of data } \\
\text { collection }\end{array}$ & $\begin{array}{l}\text { Search } \\
\text { Fields }\end{array}$ & Keywords used in the search & $\begin{array}{l}\text { Number of } \\
\text { articles }\end{array}$ \\
\hline $\begin{array}{l}\text { Quantitative } \\
\text { Analysis }\end{array}$ & $1960-2016$ & $\begin{array}{l}\text { Title, } \\
\text { abstract, } \\
\text { keywords }\end{array}$ & $\begin{array}{l}\text { Backpackers and tourism } \\
\text { Backpackers and tourism and } \\
\text { economic impact }\end{array}$ & $\begin{array}{l}118 \\
\text { (n) }\end{array}$ \\
\hline
\end{tabular}


econometric analysis, this paper aims to present and discuss backpackers' repercussion to local development and poverty alleviation based in empirical evidences or in loco observations descrived by several researchers during their field work. It is our purpose, to gather and discuss their contributions scattered in various articles on the backpacker tourism.

The following five hypotheses are tested in the study:

$\mathrm{H}$ 1: The number of research articles related to backpackers and tourism, published in the major hospitality and tourism journals, will increase over time.

$\mathrm{H} 2$ : The number of research articles related to the economic impacts of backpackers' tourism, published in the major hospitality and tourism journals, will increase over time.

H3: The most relevant research articles for analysis related to backpackers contribution to local development and poverty alleviation, published in the major hospitality and tourism journals over time, has been conducted in developing countries.

$\mathrm{H} 4$ : The majority of the research articles related to backpackers and tourism, published in the major hospitality and tourism journals, are empirical researches.

$\mathrm{H} 5$ : The majority of the research articles related to backpackers and tourism, published in the major hospitality and tourism journals, will reveal the economic impact of backpacker tourism.

H6: The majority of the research articles related to backpackers and tourism, published in the major hospitality and tourism journals, will reveal the backpacker's contribution to development and poverty alleviation.

\section{Results}

The analysis of the results will consider the (i) number of published articles; (ii) scale of analysis; (iii) type of research; and (iv) research method and analytical tools

First stage - Quantitative analysis - Number of published articles

The number of published articles on 'backpackers and tourism' $(n=118)$ not being very high, shows some interest of researchers on this issue, however, were identified only 37 articles related to the economic impact of backpacker tourism, subsequently filtered

Table 2. Evolution of the number of articles found in Scopus, 1995-2016.

\begin{tabular}{lcccccc}
\hline \multicolumn{7}{c}{ Keywords used in the search } \\
\hline Year & $\begin{array}{c}\text { Backpacker } \\
\text { and tourism }\end{array}$ & $\%$ & $\begin{array}{c}\text { Backpacker, tourism and } \\
\text { economic impact }\end{array}$ & $\%$ & $\begin{array}{c}\text { Relevant articles } \\
\text { for analysis }\end{array}$ & $\%$ \\
\hline $2016^{*}$ & 4 & 3.4 & 2 & 5.4 & 1 & 4.5 \\
2015 & 16 & 13.6 & 2 & 5.4 & 1 & 4.5 \\
2014 & 8 & 6.8 & 4 & 10.8 & 1 & 4.5 \\
2013 & 12 & 10.2 & 4 & 10.8 & 3 & 13.6 \\
2012 & 9 & 7.6 & 1 & 2.7 & 1 & 4.5 \\
2011 & 3 & 2.5 & 3 & 8.1 & 2 & 9.1 \\
2010 & 5 & 4.2 & 1 & 2.7 & 1 & 4.5 \\
2009 & 4 & 3.4 & 1 & 2.7 & 0 & 0.0 \\
2008 & 6 & 5.1 & 2 & 5.4 & 1 & 4.5 \\
2007 & 11 & 9.3 & 6 & 16.2 & 3 & 13.6 \\
2006 & 14 & 11.9 & 1 & 2.7 & 2 & 9.1 \\
2005 & 1 & 0.8 & 0 & 0.0 & 0 & 0.0 \\
2004 & 4 & 3.4 & 1 & 2.7 & 0 & 0.0 \\
2003 & 7 & 5.9 & 3 & 8.1 & 3 & 13.6 \\
2002 & 3 & 2.5 & 1 & 2.7 & 1 & 4.5 \\
2001 & 3 & 2.5 & 1 & 2.7 & 0 & 0.0 \\
2000 & 2 & 1.7 & 2 & 5.4 & 1 & 4.5 \\
1999 & 2 & 1.7 & 1 & 2.7 & 0 & 0.0 \\
1998 & 2 & 1.7 & 1 & 2.7 & 1 & 4.5 \\
1997 & 1 & 0.8 & 0 & 0.0 & 0 & 0.0 \\
1995 & 1 & 0.8 & 0 & 0.0 & 0 & 0.0 \\
Total & 118 & $\mathbf{1 0 0}$ & $\mathbf{3 7}$ & $\mathbf{1 0 0}$ & $\mathbf{2 2}$ & $\mathbf{1 0 0}$ \\
\hline * & 1 & 1 & &
\end{tabular}


through the careful reading of the abstract. It was not possible to download 12 articles, but the reading of their abstracts has been carried out. The most relevant were subsequently searched in the Google Scholar search engine and some authors contacted by email. In total, 27 articles were read, and of these, 5 were excluded, because their analyses were not relevant to our objectives. The oldest article searched was published in 1998.

The analysis of Table 2 allows us to conclude that the interest of tourism researchers on backpackers is relatively recent, with the first article being published only in 1995. The majority of works was performed during the first and second decade of the 21st century with special emphasis on the years 2006, 2007, 2013 and 2015. This finding supports and validates the Hypotheses 1. The same trend was observed for the research published about the economic impacts of backpacker tourism, highlighting the years 2007, 2013 and 2014, validating Hypotheses 2.

The scientific journals that have published more articles on backpacker tourism were the Annals of Tourism Research $(\mathrm{n}=14)$, Tourism Management $(n=6)$ and Tourist Studies $(n=6)$. On the topic of economic impacts of this tourists segment, stand out the Annals of Tourism Research $(n=4)$, Journal of Sustainable Tourism $(\mathrm{n}=3), \quad$ Tourism Geographies $(\mathrm{n}=3)$ the Current Issues in Tourism $(n=2)$ and Journal of China Tourism Research $(n=2)$, on the whole they, published $40 \%$ of researched articles (Table 3 ). The vast majority of works $(60 \%)$ are dispersed by 21 distinct journals (Table 3), identified in Scopus as belonging to two main scientific areas: Social Sciences and Business, Management and Accounting. With less incidence, there are the Environmental Science, Arts \& Humanities and Medicine. On the economic impact of

Table 3. Number of articles published in scientific journals on the topic, economic impacts of backpacker tourism 1998-2015.

\begin{tabular}{llll}
\hline & $\begin{array}{l}\text { No. } \\
\text { Articles }\end{array}$ & $\%$ & $\begin{array}{l}\text { Freq. } \\
\text { Accumulated (\%) }\end{array}$ \\
\hline Annals of Tourism Research & 4 & 11.4 & 11.4 \\
Journal of Sustainable Tourism & 3 & 8.6 & 20.0 \\
Tourism Geographies & 3 & 8.6 & 28.6 \\
Current Issues in Tourism & 2 & 5.7 & 34.3 \\
Journal of China Tourism Research & 2 & 5.7 & 40.0 \\
BMC Public Health & 1 & 2.9 & \\
CDR Working Paper & 1 & 2.9 \\
Canadian Journal of Human Sexuality & 1 & 2.9 & \\
Cuadernos De Turismo & 1 & 2.9 & \\
Development Southern Africa & 1 & 2.9 & \\
Eco Mont & 1 & 2.9 & \\
Ecological Economics & 1 & 2.9 & \\
Geography & 1 & 2.9 & \\
International Journal of Tourism Research & 1 & 2.9 & \\
Journal for the Study of Religions and Ideologies & 1 & 2.9 & \\
Journal of Hospitality and Tourism Research & 1 & 2.9 & \multirow{2}{*}{60.0} \\
Journal of Travel Medicine & 1 & 2.9 & \\
Journal of Travel Research & 1 & 2.9 & \\
People and Place & 1 & 2.9 & \\
Socialni Studia & 1 & 2.9 & \\
Tijdschrift Voor Economische En Sociale Geografie & 1 & 2.9 & \\
Tourism Analysis & 1 & 2.9 & \\
Tourism Economics & 1 & 2.9 & \\
Tourism Management & 1 & 2.9 \\
Tourism Management Perspectives & 1 & 2.9 \\
Tourist Studies & 1 & 2.9 \\
Total & 35 & 100 & \multirow{2}{*}{$\mathbf{1 0 0}$} \\
\hline
\end{tabular}


backpackers, we also emphasise the scientific area of Economics, Econometrics and Finance (Table 4).

\section{Second stage - Qualitative Analysis}

In a second stage, was carried out a qualitative analysis based on a full reading of the more relevant 22 selected articles. The data was divided as follows: analysis dimensions, localization and methodology used in empirical studies.

\section{Scale of analysis}

The majority of the analysed studies $(n=12)$ held its empirical analysis in small communities and/or cities that are major international tourist destinations - geographic large scale analysis; seven articles $(n=7)$ expanding their analysis scale at a national level and only one study $(n=1)$ performs its empirical analysis on a geographical regional scale (Tibet). It was also considered relevant to distinguish the development level of the countries in which were carried out empirical analysis $(n=22)$, having been used for the purpose, the ranking of Human Development Index 2015 (UNDP, 2015): eight studies $(n=8)$ focus on communities, cities or regions located in nine developing countries and 7 studies were conducted in territories located in only two Developed Countries (Australia and New Zealand) (Table 5). Considering the findings it's possible to validate the Hypotheses 3 , because the findings reveal that the main focus of the empirical studies are on small communities, cities or regions, located mostly in developing countries.

\section{Type of research}

In all studies, authors proceeded to the collection and the exclusive use of primary data, with the exception of the study carried out by Gibson \& Connell (2003) and Rogerson (2007b) who used both, primary data (interviews) and secondary data (official statistics). This finding supports the Hypotheses 4. The lack of statistical information about youth tourism and more specifically, about backpacker tourism is symptomatic of this reality. Only Australia and New Zealand collect and periodically publish information on this tourism segment.

\section{Research method and analytical tools}

The most frequently methods used in the collection of primary data in the context of the empirical studies were the interviews and questionnaires (table 5). Interviews were used by Daldeniz \& Hampton (2013); Ho, Lin, \& Huang (2012); Lloyd (2003); Moscardo, Konovalov, Murphy, \& McGehee (2013) and Rogerson (2007b).

Questionnaires were the technique used in the works of Becken \& Simmons (2008), Dayour et al., (2016), Ooi \& Laing (2010) and Rogerson (2007a). But in order to collect information a set of techniques and tools associated with each other (mixed), such as, the field work, the participatory observation, semi-structured inter-

Table 4. Scientific Area of researched articles.

\begin{tabular}{lcc}
\hline & $\begin{array}{c}\text { Backpacker and } \\
\text { tourism }\end{array}$ & $\begin{array}{c}\text { Backpacker, tourism } \\
\text { and economic impact }\end{array}$ \\
\hline Social Sciences & 75 & 28 \\
Business, Management and Accounting & 68 & 21 \\
Environmental Science & 12 & 4 \\
Arts and Humanities & 10 & 3 \\
Medicine & 10 & 3 \\
Earth and Planetary Sciences & 4 & 1 \\
Computer Science & 4 & - \\
Engineering & 3 & - \\
Economics, Econometrics and Finance & 3 & 2 \\
Psychology & 2 & 1 \\
Agricultural and Biological Sciences & 2 & 1 \\
Immunology and Microbiology & 1 & - \\
Energy & 1 & - \\
Mathematics & 1 & - \\
\hline
\end{tabular}




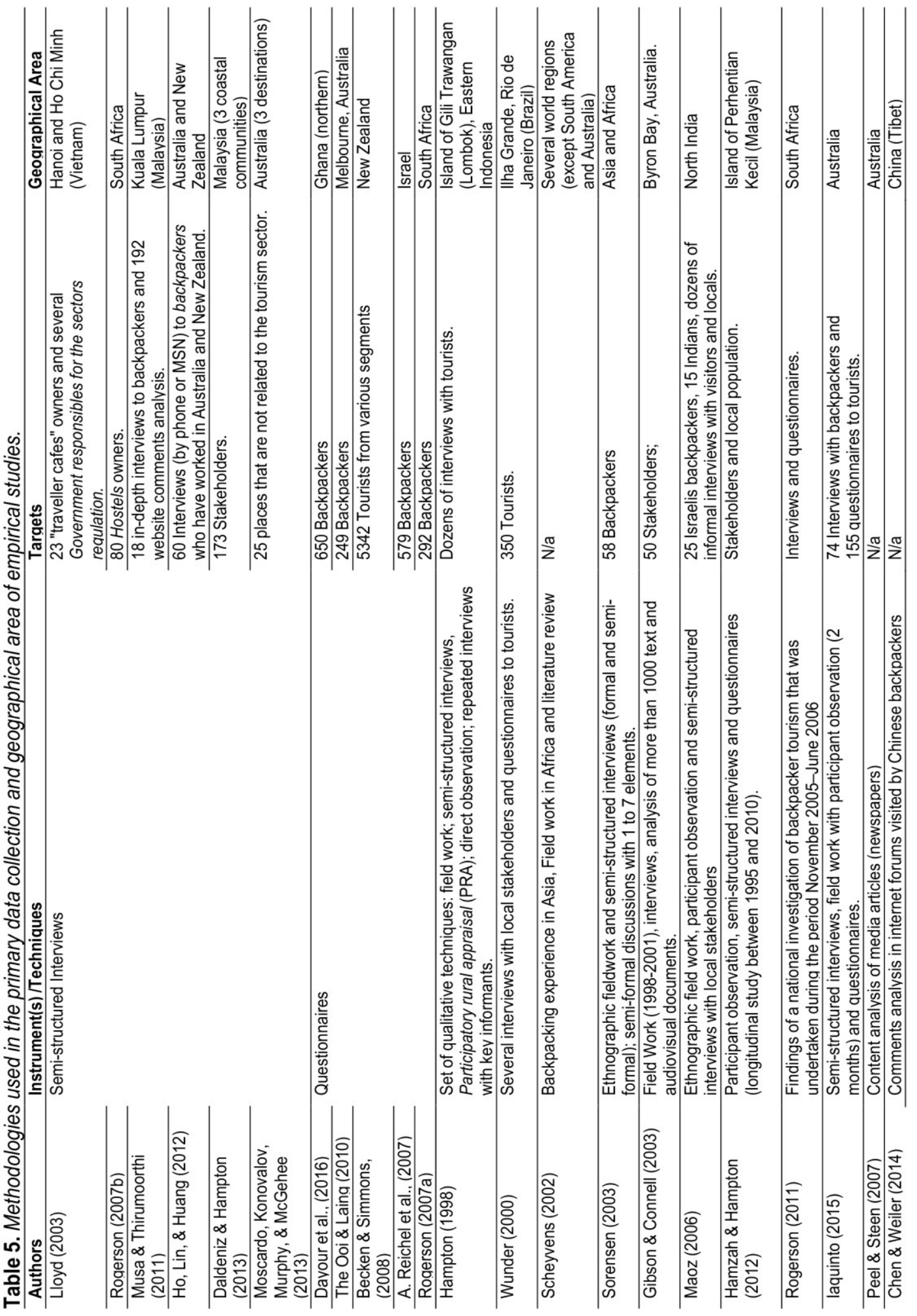


views, semi-formal discussions or questionnaires, were used in the majority of analysed articles (Gibson \& Connell, 2003; Hampton, 1998; Hamzah \& Hampton, 2012; laquinto, 2015; Maoz, 2006; Sorensen, 2003; Wunder, 2000).

In some cases, it also has been taken into account, the researcher backpacker experience (Scheyvens, 2002; Sorensen, 2003). The use of mixed techniques goes in line with the anthropological and ethnographic framework of the empirical researches as it happens with sustainability assessment studies. Questionnaires were preferably used by a more quantitative nature researches. Scheyvens (2002) work, based in her backpacking experience in Asia, her fieldwork in Africa and literature review can be categorized as theoretical research.

\section{Analysis and Discussion}

Some of the analysed studies suggest that, by remaining for longer periods in a destination, backpackers spend more than other tourists and have more contact with locals, acquiring them more services, contributing to a greater impact on local economy (Becken \& Simmons, 2008; Gibson \& Connell, 2003; Hampton, 1998; laquinto, 2015; Lloyd, 2003; Maoz, 2007; Moscardo et al. , 2013; Musa \& Thirumoorthi, 2011; Ooi \& Laing, 2010; Peel \& Steen, 2007; Scheyvens, 2002; Wunder, 2000). The UNWTO \& WYSE Travel Confederation (2010) also underlines their higher probability to visit again the same destination (loyalty), describing the tourists destinations with more young people as more resilient, not being subject to the market volatility and recovering even more quickly of eventual crises. It is in this context that backpacker tourists fit, as a modern phenomenon that results, among others, from accessibility improvements, the advent of low cost airline companies and the development of new communication technologies, and because of that is also being regarded as a complex object of study consisting of a growing, diverse and dynamic group of visitors that Richards \& Wilson (2004) designate by global nomads. Due to their complexity and to the various subsegments that have been identified, it is considered, in this meta-analysis, that a backpacker tourist is a person hosted one or more nights in a backpackers accommodation or hostel, as defined by Tourism Research Australia (2009).

After the reading of selected works, there is a crucial aspect that deserves to be highlighted: the lack of a quantitative nature works that aim the assessment of total economic effects (direct, indirect and induced) of backpacker segment. The findings, therefore, are not supportive for Hypotheses 5. Becken \& Simmons (2008) developed a set of yield indicators to define the 'ideal visitor type' measuring yield of different tourist types in New Zealand, quantifying the average expenditure per day of different segments. Using an econometric analysis, Dayour et al. (2016) investigates, in a very recent article, the determinants of backpackers' aggregate expenditure and their spending on various goods including accommodation, food and beverages and attractions in Ghana.

It will be fair, then, to say that this segment has a real and effective economic impact on destinations? The existing empirical evidences of quantitative nature will be sufficient to corroborate these impacts? First, the recursive effects on income, output and employment caused by the injection of cash into an economy by backpacker tourism were not analysed yet by any article available in Scopus database, but despite few empirical evidences, we can assume that several positive impacts have been observed and described.

The most complete work with focus on backpackers' contribution to development and poverty alleviation was done by Scheyvens (2002), through a profound literature review, where it is discussed the role of backpacker tourism in promoting local development in underdeveloped regions. In an identical perspective, although with some observed and empirical evidences, Hampton (1998) makes a comparison between the backpacker tourism and the so-called conventional tourism, discussing, among others, the capital leakage, arguing that at an economic level, the encouragement of responsible tourism has the potential to alleviate poverty, increase local participation in the development process, contributing to contradict some of the mass 

directions for future research.

tourism excesses, an idea shared by Rogerson (2011). It is recognized that backpacker tourism contributes to the development of telecommunications and transport networks, to the demand for budget accommodation and a parallel structure for restaurants and a range of other services to support tourism activity (Hampton, 1998). Overall, promotes a set of opportunities for the development of a more responsible tourism and strain relief of poverty, particularly in poorer regions usually on the fringes of the main and traditional tourist routes (Rogerson, 2011). Traveling in a wider geographical area, sometimes isolated regions, and consuming local goods, backpackers contribute to the rise of businesses that do not require large investments providing additional income, substantial for many families (Hampton, 1998; Rogerson, 2011; Scheyvens, 2002; Wunder, 2000).

Focusing these studies in developing countries, where poverty and underdevelopment are more relevant, Hampton (2003) questions if backpacker tourism provides, effectively, to local communities, a mean of entry into the globalization process, emphasising that over time, with tourist destinations development, foreign investment is attracted as it happens with other segments of tourists frequently regarded as more profitable by the majority of the governments. Therefore, it can be seen a decrease in the control and ownership by the local population, a situation examined more recently by Hamzah \& Hampton (2012). These authors followed the changes, problems and tensions arising from the multinationals installation and the response of small local stakeholders to this same reality through an original longitudinal investigation. With the tourism massification in the studied communities, backpackers started to avoid it, but the small local operators experience, more flexible and more able to respond changes, adapted to the new technologies and instead of marginalisation, were able to respond to difficulties and to the creation of a new touristic system in destination, able to satisfy the new demand (Hamzah \& Hampton, 2013), contradicting Cohen's idea (1982) cited in Scheyvens (2002) that not having the tools, expertise or resources to provide services for luxury tourists, firms providing tourist services tend to be owned by foreigners. The experience gained in services provision to backpacker segment, seems, therefore, to have contributed to the acquisition and dissemination of skills that make the local stakeholders more resilient to face new challenges. Nonetheless, in a study about the economic, environmental and social consequences of scuba diving tourism in developing countries, Daldeniz \& Hampton (2013), despite admit that alternative tourism forms originate a greater involvement and bring more benefits to the local communities in developing countries, there are few companies of diving which employ local workers due to the lack of qualifications required in this type of activities. In their empirical evidences they conclude that few businesses were opened by locals and few have managed to find a job (especially low-skilled) either due to financial constraints, English language difficulties or the little desire to stay and work in their communities.

Another aspect to take into account about backpacker tourism is their lower contribution to capital leakage (Table 6), as a result of lower investment required to satisfy this segment demand, due to the lower consumption of imported products and services and by the fact that the profits stay in the community (Hampton, 1998; Hamzah \& Hampton, 2012; Musa \& Thirumoorthi, 2011; Wunder, 2000). Government encouragement to the backpacker tourism development constitute another topic worthy of attention (Table 6). Neglected or ignored by the majority of developing countries, due to the reduced daily spending associated with this segment, it is more common the incentive to large foreign investment (Hamzah \& Hampton, 2013). Hampton (2003) reinforces the idea that the developing countries governments should give more attention to backpacker tourism, point of view highlighted by Rogerson (2011) that emphasizes the change in attitude of South African authorities, who since 2006 began to recognize its importance as happened with the Malaysian authorities in 2008 (Musa \& Thirumoorthi, 2011) where $10 \%$ of international tourists are backpackers. These changes in attitude, which 
are in concordance with the growing interest of international researchers about the economic impact of backpacker tourism, is in line with the idea that promoting this segment, is investing in the future, increasing the probability of customer loyalty. Considering the findings it's possible to validate the Hypotheses 6.
But will the backpacker tourists of today be the wealthy tourists of the future? Hampton (2003) and Rogerson (2011) suggests that backpackers tend to be the last to abandon a destination in situations of crisis and the first to return when the conditions improve, situation recognized by Peel \& Steen (2007) who admit

Table 6. Backpacker tourism contributions to local development and poverty alleviation.

Local development and poverty alleviation benefits Spend more money than other tourists, due to its longer staying, contributing to a significant entry of foreign currency.

\section{Authors}

Becken \& Simmons (2008); Hampton (1998);

laquinto (2015); Lloyd (2003); Maoz (2006);

Moscardo et al. (2013); Musa \& Thirumoorthi

(2011); Ooi \& Laing (2010); Peel \& Steen

(2007); Scheyvens (2002)

Spend more money through a wider area, including the most remote, isolated and economically depressed.

Do not buy luxury products, spending more on local goods and services (catering, transport and accommodation).

The economic benefits spread widely to a greater number of local workers because business investments and the necessary qualifications are not very high.

The necessary infrastructures are basic, decreasing the initial investments and minimizing the importation of goods.

Contributes to capital leakage reduction and for the increase of induced effects, promoting the mitigation of extreme poverty.

Important multiplier effects due to the use of resources and local labor.

The firms providing services to backpackers are small and their owners are locals.

Local owners can create organizations in order to promote local tourism towards their interests and aspirations, gaining bargaining power.

Consume less energy resources, contributing to environmental preservation.

Local firm owners who operate in the local market tourist industry challenge the dominance of multinational companies.

The backpacker tourists constitute an important temporary workforce, in the agricultural sector and tourism.

The backpacker tourists constitute a large part of the international volunteering who contributes to the realization of social, cultural or economic nature projects.

Greater probability of backpacker tourists repeat Rogerson (2011) the visit (loyalty).

Source: Becken \& Simmons (2008), Chen \& Weiler (2014), Dayour et al. (2016), Gibson \& Connell (2003); Hampton (1998), Hamzah \& Hampton (2013), laquinto (2015), Lloyd (2003), Maoz (2006), Moscardo et al. (2013), Musa \& Thirumoorthi (2011), Ooi \& Laing (2010), Peel \& Steen (2007), Rogerson (2011), Scheyvens (2002), Wunder (2000)
Dayour et al., (2016); laquinto (2015); Maoz

(2006); Musa \& Thirumoorthi (2011); Peel \&

Steen (2007); Rogerson (2011); Scheyvens

(2002)

Gibson \& Connell (2003); laquinto (2015); Maoz

(2006); Ooi \& Laing (2010); Moscardo et al.

(2013); Scheyvens (2002); Wunder (2000)

Dayour et al., (2016); Hamzah \& Hampton

(2013); Ooi \& Laing (2010); Rogerson (2011);

Scheyvens (2002)

Hampton (1998); Ooi \& Laing (2010); Scheyvens (2002)

Dayour et al., (2016); Hampton (1998); Hamzah

\& Hampton (2013); Musa \& Thirumoorthi (2011);

Wunder (2000)

Chen \& Weiler (2014); Hampton (1998);

Scheyvens (2002)

Hampton (1998); Maoz (2006); Scheyvens

(2002)

Hampton (1998); Scheyvens (2002)

laquinto (2015); Ooi \& Laing (2010). Scheyvens (2002); Wunder (2000)

Hamzah \& Hampton (2013); Scheyvens (2002)

laquinto (2015); Moscardo et al. (2013); Peel \& Steen (2007)

The Ooi \& Laing (2010); Rogerson (2011) 

directions for future research.

backpackers relative indifference to risk, a characteristic that will have contributed to increase the value of this segment.

The Australian authorities that have been promoting this segment since mid-1990, recognize backpackers as an important market niche that represented in 2004 approximately $20 \%$ of the total incomes from international tourism (Peel \& Steen, 2007). Similar approach has been followed by neighbouring New Zealand. The work of Gibson \& Connell (2003) reflects the impact of backpackers in a small coastal community in Australia, where the specialisation in certain cultural events related to music and dance had a significant economic impact in the region. Among the articles in analysis there is also a set of studies dedicated to hostels, whose increased offer is often used as a good indicator of the number of backpackers evolution (Gibson \& Connell, 2003; Lloyd, 2003; Rogerson, 2007a, 2007b; Wunder, 2000). While Musa \& Thirumoorthi (2011) analyse the importance of service quality provided in hostels, Lloyd (2003) investigated the impact of government regulation of hostels or "traveller cafes" in Vietnam, concluding the existence of erratic responses from government authorities, which induced by stereotypes, and not having initially supported the development of backpacker tourism private sector, recognizing its economic impacts, began to encourage the creation of state-owned enterprises to compete with the private sector in low cost tourism segment.

In the same line of research, Rogerson (2007a), aware of the economic importance of youth tourism, emphasizes the need to create a strategic development policy on backpacker tourism in South Africa. Developing a research oriented under the business perspective of hostels, several barriers to hostel industry competitiveness were identified as the lack of official recognition or the lack of collection and treatment of statistical data (Rogerson, 2007b).

Another area of interest analysed by selected articles is the concern about the sustainability of backpacker tourism. Trying to find the ideal type of visitor regarding the sustainability of various tourists segments, Becken \& Simmons
(2008) analysed the impact on the environment, on the economy and also in terms of costs to the public sector, having concluded that Backpackers and campers have a major economic impact by spending more and by dispersing in a larger area, even if they visit a large number of public attractions representing therefore, higher costs for the State. Moscardo et al. (2013) showing the positive and negative impacts of tourists in three Australian destinations, recognize that backpackers are an important temporary workforce in agriculture, especially during the harvest. Since a large number of backpackers is "holiday-maker" (Ho et al., 2012) their extended stay also makes them important sources of funding for local economy, idea already supported by Peel \& Steen (2007) and, more recently, by laquinto (2015) who concludes that when backpackers engaged in a work activity at the destination, the economic, social and environmental sustainability is mutually reinforced. Another way backpackers can contribute positively to destinations sustainability is the creation and development of volunteer tourism. The potential alignment between these two market segments, that share motivations, was explored by Ooi \& Laing (2010) suggesting the creation of activities designed specifically to this segment.

\section{Conclusions}

The existence of few studies concerning the economic impacts of backpacker tourism has contributed to the maintenance of harmful attitudes by some developing countries authorities in relation to this segment (Hampton, 2003). Different approach has been taken by Australian governments, which since 1994 have encouraged and promoted with success the development of this segment, eventually capturing the interest of some international hotel groups such as the French Accor or the Japanese Daikyo's (Peel \& Steen, 2007). Being a heterogeneous and complex group (Sorensen, 2003), consisting of a large number of sub-segments (Figure 1), backpackers can increase the business opportunities in many destinations that decide to invest on their promotion. Despite the reduce amount of research about backpackers' contribution to development and poverty alleviation and some 
harmful attitudes by some developing countries authorities in relation to this segment (Hampton, 2003) there are several benefits revealed in analysed articles that support the idea that backpacker tourists give an important contribution to local development and poverty alleviation. The potential of backpacker tourism as a tool for real economic development and poverty alleviation requires thorough evaluation by LDC government planners and international development agencies.

Those responsible for destinations planning and management, will be able to conduct marketing strategies to segments that are best adapted to local or regional reality, bringing with it, important competitive advantages, as has happened in some Australian regions (Gibson \& Connell, 2003). Because of that, more research on backpackers' expenditure should be done. Moreover, if communities maximize the benefits from backpacker tourism without compromising their cultures, their environments or their general social-well-being, further research on backpacker tourism should be considered.

The systematic review of literature published in scientific articles about the economic relevance of backpacker tourism revealed important gaps:

1. Backpacker's injection of cash and its effects on income, output and employment into local, regional or national economies was not analysed. A model to quantify the economic impacts that express objectively the benefits of this tourism segment in several indicators such as the payments balance (increasing exports), increase production, state revenues and incomes rising has not yet developed.

2. The need to carry out more quantitative and comparative studies, not only on economic impact but also on cost-benefit analysis more concerned with overall economic efficiency and social welfare measures.

3. It was also clear the need to better understand the multiplier effects of the economic impact of backpacker tourism (Hampton, 1998), assess and quantify their indirect and induced effects with an appropriate models.

4. Relate backpackers' expenditure with some variables including nationality, gender, level of education, length of stay and with several visit motivations as recently done by Dayour et al. (2016) in different countries could be an opportunity to go further.

5. It's important to diversify the geographical areas of empirical studies to other regions in the world, in particular, Europe, South America and Africa.

6. Since there are not many quantitative data collected and analysed by statistical official agencies about backpacker tourism, is relevant to conduct further research to quantify the economic impact both in developed countries as in developing countries.

7. Establish ongoing monitoring of the positive and negative impacts of tourism, to determine whether or not this business as they are pursuing it offers an appropriate form of development for their community

8. Examination of whether the sector itself goes through various stages (for instance, when do the parallel structures and specialist services start to appear such as private buses rather than purely local transport).

The backpacker tourism should also be considered by countries authorities where the tourism sector is already well established and developed, as a further way of diversifying the offer, focusing, for example, in its promotion in more peripheral regions that usually find themselves at the margins of the main tourist flows.

The size of study the area is an important issue that should be taken in account on economic regional impact and contribution analysis to avoid results manipulations (Watson et al., 2007). Choosing a relatively small study area will make backpacker tourism look very important, but if the study area is very large, it will dilute backpacker tourism relative importance.

\section{References}

Archer, B., \& Fletcher, J. (1996). The economic impact of tourism in the Seychelles. Annals of Tourism Research, 23(1), 32-47. http: //doi.org/10.1016/0160-7383(95)00041-0

Becken, S., \& Simmons, D. (2008). Using the concept of yield to assess the sustainability of different tourist types. Ecological Economics, 67(3), 420-429. http://doi.org/ 10.1016/j.ecolecon.2007.12.025

Chen, H., \& Weiler, B. (2014). Chinese Donkey Friends in Tibet - Evidence from the 
Backpackers' contribution to development and poverty alleviation, myth or reality? A critical review of the literature and directions for future research.

Cyberspace Community. Journal of China Tourism Research, 10(4), 475-492. http: //doi.org/10.1080/19388160.2014.951503

Cohen, E. (1972). Toward a sociology of international tourism. Social Research, 39(1), 164-182.

Daldeniz, B., \& Hampton, M. P. (2013). Dive Tourism and Local Communities: Active Participation or Subject to Impacts? Case Studies from Malaysia. Internations/ Journal of Tourism Research, 15, 507-520. http://doi.org/10.1002/jtr

Dayour, F., Adongo, C. A., \& Taale, F. (2016). Determinants of backpackers' expenditure. Tourism Management Perspectives, 17, 3643. http://doi.org/10.1016/j.tmp.2015.11.003

Elsevier. (2014). Scopus. Retrieved from http://www.elsevier.com/_data/assets/pdf_f ile/0007/148714/3859-Scopus-Facts-andFigures-LO.pdf

Gibson, C., \& Connell, J. (2003). "Bongo fury": Tourism, music and cultural economy at Byron Bay, Australia. Tijdschrift Voor Economische En Sociale Geografie, 94(2), $164-187 . \quad$ http://doi.org/10.1111/14679663.00247

Hampton, M. (1998). Backpacker tourism and economic development. Annals of Tourism Research, 25(3), 639-660. http://doi.org/ 10.1016/S0160-7383(98)00021-8

Hampton, M. (2003). Entry points for local tourism in developing countries: Evidence from yogyakarta, Indonesia. Geografiska Annaler, Series B: Human Geography, 85(2), 85-101. http://doi.org/10.1111/14680467.00133

Hampton, M., \& Hamzah, A. (2010). The changing Geographies of Backpacker tourism in south-east Asia. Working Paper No.210. Co-Published as Centre For Innovative Planning \& Development Monograph 3(2010). Faculty of the Built Environment Universiti Teknologi Malaysia.

Hamzah, A., \& Hampton, M. P. (2013). Resilience and Non-Linear Change in Island Tourism. Tourism Geographies, 15(1), 4367. http://doi.org/10.1080/14616688.2012. 675582

Ho, C.-I., Lin, P.-Y., \& Huang, S.-C. (2012). Exploring Taiwanses Working HolidayMarkers' Motivations: An Analysis of MeansEnd Hierarchies. Journal of
Hospitality \& Tourism Research, 38(4), 463486. http://doi.org/10.1177/109634801246 1549

laquinto, B. L. (2015). "I recycle, I turn out the lights": understanding the everyday sustainability practices of backpackers. Journal of Sustainable Tourism, 23(4), 577599. http://doi.org/10.1080/09669582.2014. 978788

Klijs, J., Heijman, W., Maris, D. K., \& Bryon, J. (2012). Criteria for comparing economic impact models of tourism. Tourism Economics, 18(6), 1175-1202. http://doi.org/10.5367/te.2012.0172

Lloyd, K. (2003). Contesting control in transitional -Vietnam: The development and regulation of traveller cafés in Hanoi and Ho Chi Minh City. Tourism Geographies, 5(3), 350-366.

http://doi.org/10.1080/14616680309717

Loker-Murphy, L., \& Pearce, P. L. (1995). Young budget travelers: Backpackers in Australia. Annals of Tourism Research, 22(4), 819-843. http://doi.org/10.1016/01607383(95)00026-0

Maoz, D. (2006). The mutual gaze. Annals of Tourism Research, 33(1), 221-239. http://doi.org/10.1016/j.annals.2005.10.010

Maoz, D. (2007). Backpackers' motivations the role of culture and nationality. Annals of Tourism Research, 34(1), 122-140. http://doi.org/10.1016/j.annals.2006.07.008

Mayer, M., Müller, M., Woltering, M., Arnegger, J., \& Job, H. (2010). The economic impact of tourism in six German national parks. Landscape and Urban Planning, 97(2), 7382. http://doi.org/10.1016/j.landurbplan. 2010.04.013

Moscardo, G., Konovalov, E., Murphy, L., \& McGehee, N. (2013). Mobilities, community well-being and sustainable tourism. Journal of Sustainable Tourism, 21(4), 532-556. http://doi.org/10.1080/09669582.2013.7855 56

Murphy, L. (2001). Exploring social interactions of backpackers. Annals of Tourism Research, 28(1), 50-67. http://doi.org/ 10.1016/S0160-7383(00)00003-7

Musa, G., \& Thirumoorthi, T. (2011). Red Palm: exploring service quality and servicescape of the best backpacker hostel in Asia. Current Issues in Tourism, 14(2), 103-120. 
http://doi.org/10.1080/13683500903511125

Ooi, N., \& Laing, J. H. (2010). Backpacker tourism: sustainable and purposeful? Investigating the overlap between backpacker tourism and volunteer tourism motivations. Journal of Sustainable Tourism, 18(2), 191-206. http://doi.org/10.1080/09669580903395030

Paris, C. M. (2012). Flashpackers: An Emerging Sub-Culture? Annals of Tourism Research, 39(2), 1094-1115. http://doi.org/10.1016/j.annals.2011.12.001

Peel, V., \& Steen, A. (2007). Victims, hooligans and cash-cows: media representations of the international backpacker in Australia. Tourism Management, 28(4), 1057-1067. http://doi.org/10.1016/j.tourman.2006.08.01 2

Reichel, A., Fuchs, G., \& Uriely, N. (2007). Perceived Risk and the Non-Institutionalized Tourist Role: The Case of Israeli Student Ex-Backpackers. Journal of Travel Research, 46(2), 217-226. http://doi.org/10.1177/0047287507299580

Reichel, A., Fuchs, G., \& Uriely, N. (2009). Israeli backpackers. The Role of Destination Choice. Annals of Tourism Research, 36(2), 222-246.

http://doi.org/10.1016/j.annals.2008.11.002

Richards, G., \& Wilson, J. (2004). The Global Nomad, Backpacker Travel in Theory and Practice. (G. Richards \& J. Wilson, Eds.). Clevedon: Channel View Publications.

Riley, P. J. (1988). Road culture of international long-term budget travelers. Annals of Tourism Research, 15(3), 313-328. http: //doi.org/10.1016/0160-7383(88)90025-4

Rogerson, C. M. (2007a). Backpacker Tourism in South Africa: Challenges and Strategic Opportunities. South African Geographical Journal, 89(2), 161-171. http://doi.org /10.1080/03736245.2007.9713886

Rogerson, C. M. (2007b). The challenges of developing backpacker tourism in South Africa: an enterprise perspective. Development Southern Africa, 24(3), 425444 . http://doi.org/10.1080/0376835070 1445533

Rogerson, C. M. (2011). Youth Tourism in Africa: Evidence from South Africa. Tourism Analysis, 16(2), 105-120. http://doi.org/ 10.3727/108354211X13014081270206

Scheyvens, R. (2002). Backpacker tourism and
Third World development. Annals of Tourism Research, 29(1), 144-164. http://doi.org/10.1016/S01607383(01)00030-5

Sørensen, A. (2003). Backpacker ethnography. Annals of Tourism Research, 30(4), 847867. http://doi.org/10.1016/S0160-7383(03) 00063-X

Tourism Research and Marketing. (2013). New horizons III, Executive Summary. Amsterdam. Retrieved from https:// www.wysetc. org/wp-content/uploads /2014/11/ newhorizonsiii-v7-execsummary-v4s.pdf

Tourism Research Australia. (2009). Backpacker accommodation in Australia 2009. Retrieved from http://www.tra. gov.au/documents/Snapshots_2009_Backp acker_FINAL.pdf

Tourism Victoria. (2009). Backpacker Tourism Action Plan 2009-2013. Melbourne, Victoria. Retrieved from http://www.tourism .vic.gov.au/images/stories/Documents/Strat egiesandPlans/Backpacker-Tourism-ActionPlan-2009.pdf

UNDP (2015). Human Development Report 2015, Work for Human Development. United Nations, New York, 288p. Retrieved from http://report.hdr.undp.org/

UNWTO, \& WYSE Travel Confederation. (2010). The power of youth travel.

Vogt, J. W. (1976). Wandering: Youth and travel behavior. Annals of Tourism Research, 4(1), 25-41. http://doi.org/ 10.1016/0160-7383(76)90051-7

Wagner, J. E. (1997). Estimating the economic impacts of tourism. Annals of Tourism Research, 24(3), 592-608. http://doi.org/10.1016/S01607383(97)00008-X

Watson, P., Wilson, J., Thilmany, D., \& Winter, S. (2007). Determining Economic Contributions and Impacts: What is the difference and why do we care? Journal of Regional Analysis And Policy, 37(2), 140146.

Wunder, S. (2000). Big island, green forests and Backpackers, Land-use and development options on Ilha Grande, Rio de Janeiro State, Brazil. CDR Working Papers 00.4. 


\section{Appendix \\ List of selected and analysed articles in the meta-analysis}

Becken, S. , \& Simmons, D. (2008). Using the concept of yield to assess the sustainability of different tourist types. Ecological Economics, 67(3), 420-429. http: //doi.org/10.1016/j.ecolecon.2007.12.025

Chen, H. , \& Weiler, B. (2014). Chinese Donkey Friends in Tibet - Evidence from the Cyberspace Community. Journal of China Tourism Research, 10(4), 475-492. http: //doi.org/10.1080/19388160.2014.951503

Dayour, F., Adongo, C. A., \& Taale, F. (2016). Determinants of backpackers' expenditure. Tourism Management Perspectives, 17, 3643. http://doi.org/10.1016/j.tmp.2015.11.003

Daldeniz, B. , \& Hampton, M. P. (2013). Dive Tourism and Local Communities: Active Participation or Subject to Dataquest Insight? Case Studies from Malaysia. Internationsl Journal of Tourism Research, 15, 507-520. http://doi.org/10.1002/jtr

Gibson, C. , \& Connell, J. (2003). "Bongo fury": Tourism, music and cultural economy at Byron Bay, Australia. Tijdschrift Voor Economische En Sociale Geografie, 94(2), 164-187. http://doi.org/10.1111/14679663.00247

Hampton, M. (1998). Backpacker tourism and economic development. Annals of Tourism Research, 25(3), 639-660. http://doi.org/ 10.1016/S0160-7383(98)00021-8

Hamzah, A. , \& Hampton, M. P. (2013). Resilience and Non-Linear Change in Island Tourism, (March 2015), 37-41. http: //doi.org/10.1080/14616688.2012.675582

Ho, C. -I. , Lin, P. -Y. , \& Huang, S. -C. (2012). Exploring Taiwanses Working HolidayMarkers ' Motivations: An Analysis of Means-End Hierarchies. Journal of Hospitality \& Tourism Research, 38(4), 463-486. http://doi.org/10.1177/1096348012461549

laquinto, B. L. (2015). " I recycle, I turn out the lights ": understanding the everyday sustainability practices of backpackers, (March), 37-41. http://doi.org/10.1080/ 09669582.2014.978788

Lloyd, K. (2003). Contesting control in transitional Tourism Geographies, 5(3), 350366. http://doi.org/10.1080/14616680309717
Maoz, D. (2006). The mutual gauze. Annals of Tourism Research, 33(1), 221-239. http://doi.org/10.1016/j.annals.2005.10.010

Moscardo, G. , Konovalov, E. , Murphy, L. , \& McGehee presented an, N. (2013). Mobilities, community well-being and sustainable tourism. Journal of Sustainable Tourism, 21(4), 532-556. http: //doi.org/10.1080/09669582.2013.785556

Musa, G. , \& Thirumoorthi, T. (2011). Red Palm: exploring service quality and servicescape of the best backpacker hostel in Asia. Current Issues in Tourism, 14(2), 103-120.

http://doi.org/10.1080/13683500903511125

Ooi, N. , \& Laing, J. H. (2010). Backpacker tourism: sustainable and purposeful? Investigating the overlap between backpacker tourism and volunteer tourism motivations. Journal of Sustainable Tourism, 18(2), 191-206. http://doi.org/10.1080/ 09669580903395030

Peel, V. , \& Steen, A. (2007). Qa., hooligans and cash-cows: media representations of the international backpacker in Australia. Tourism Management, 28(4), 1057-1067. http://doi.org/10.1016/j.tourman.2006.08.012

Reichel, A. , Fuchs, G. , \& Uriely, N. (2007). Perceived Risk and the Non-Institutionalized Tourist Scroll: The Case of Israeli Student Ex-Backpackers . Journal of Travel Research, 46(2), 217-226. http://doi.org/10.1177/0047287507299580

Rogerson, C. M. (2007a). Backpacker Tourism in South Africa: Challenges and Strategic Opportunities. South African Geographical Journal, 89(2), 161-171. http://doi.org/ 10.1080/03736245.2007.9713886

Rogerson, C. M. (2007b). The challenges of developing backpacker tourism in South Africa: an enterprise perspective. Development Southern Africa, 24(3), 425-444. http://doi.org/10.1080/03768350701445533

Rogerson, C. M. (2011). Youth Tourism in Africa: Evidence from South Africa. Tourism Analysis, 16(2), 105-120. http://doi.org /10.3727/108354211X13014081270206

Scheyvens, R. (2002). Backpacker tourism and Third World development. Annals of Tourism Research, 29(1), 144-164. http://doi.org/10.1016/S01607383(01)00030-5 
Martins, M., Costa, R. (2017) / European Journal of Tourism Research 16 pp. 136-153

Sorensen, A. (2003). Backpacker ethnography. Annals of Tourism Research, 30(4), 847867. 7383(03)00063-X
Wunder, S. (2000). Big island, green forests and Backpackers, Land-use and development options on Ilha Grande, Rio de Janeiro State, Brazil. CDR Working Papers. URL: http://hdl.handle.net/10568/18274 